\title{
THE ROLE OF SOCIAL CAPITAL IN DISASTER MANAGEMENT OF DISASTER VULNERABLE VILLAGE COMMUNITY ON THE MERAPI ERUPTION
}

\author{
Entoh Tohani*, Lutfi Wibawa \\ Universitas Negeri Yogyakarta, Indonesia \\ *e-mail: tohani@uny.ac.id
}

\begin{abstract}
Community resilience to anticipate disaster depends on the possession of social capital that grows in the community. Social capital can produce positive effects, unfortunately, disaster mitigations have been dominated by the development of human capital skills than social capital skills. This study aims to determine the role of social capital in disaster management in the disaster vulnerable communities of the Merapi Mount, taking a case in Girikerto village, Turi Sub-district, Sleman Regency, Special Province of Yogyakarta, Indonesia as one area with high risk of the eruption. Independent interviews, and focused group discussions were done involving hamlet heads, village government officials, and members of community disaster organizations; in addition to observation in the village dailylife. The results showed that social capital covering values and norms, commitment, trust, networking and sharing of information or knowledge provides benefits in the form of increased community awareness of disaster, social solidarity, and disaster knowledge of the citizens. Therefore, it is important to held community empowerment using an educational approach that is based on the utilization of social capital directly and planned in disaster vulnerable areas for enlarging the resiliency capacity of community.
\end{abstract}

Keywords: social capital, disaster, vulnerable, empowerment, role

\section{PERAN MODAL SOSIAL DALAM PENANGANAN BENCANA PADA MASYARAKAT DESA RAWAN BENCANA ERUPSI MERAPI}

\begin{abstract}
Abstrak: Resiliensi masyarakat guna mengantisipasi bencana alam tergantung pada kepemilikan modal sosial sosial yang tumbuh dalam kehidupan. Modal sosial memberikan manfaat positif dalam upaya penanganan bencana. Namun selama ini penanganan bencana alam lebih diarahkan pada pengembangan modal manusia dibanding dengan modal sosial. Penelitian ini bertujuan untuk mengetahui peran modal sosial dalam penanggulangan bencana pada masyarakat rentan bencana erupsi Gunung Merapi. Penelitian ini merupakan studi kasus yang dilakukan di Desa Girikerto, Kecamatan Turi, Kabuptaten Sleman, Daerah Istimewa Yogyakarta sebagai desa yang sangat rawan terkena dampak bencana erupsi Merapi. Pengumpulan data dilakukan dengan wawancara independen, diskusi kelompok terarah, dan pengamatan. Informan penelitian ini yaitu kepala dusun, pejabat pemerintah desa, dan anggota organisasi bencana masyarakat. Data dianalisis dengan teknik analisis kualitatif dengan tahap reduksi, display, dan penarikan kesimpulan. Hasil penelitian menunjukkan modal sosial yang berdimensi nilai dan norma, komitmen, kepercayaan, jejaring, dan sharing informasi/pengetahuan berperan penting dalam penanganan bencana erupsi Merapi dan memberikan manfaat berupa peningkatan kesadaran masyarakat terhadap bencana, solidaritas sosial, dan pengetahuan bencana warga. Oleh karena itu, dipandang penting untuk menyelenggarakan pemberdayaan masyarakat dengan pendekatan pendidikan berbasis pendagunaan modal social di daerah rawan bencana secara terarah dan terencana guna mengembangkan kapasitas resiliensi masyarakat.
\end{abstract}

Kata Kunci: modal sosial, bencana, kerentanan, pemberdayaan, peran

\section{PENDAHULUAN}

Kejadian bencana alam dapat menimbulkan dampak negatif baik fisik maupun nonfisik pada kehidupan individu maupun masyarakat. Dampak fisik mencakup kehancuran insfrastruktur, kehilangan tempat tinggal, sanitasi yang buruk, kesulitan makanan, kehancuran ekosistem dan lingkungan, dan dampak nonfisik dapat berupa 
muncul masalah kesehatan psikologi misal stress dan kegilaan, perubahan gaya hidup, kerusakan aktivitas bisnis, bahkan luka atau kematian. Walaupun disadari pula, setelah berlangsung bencana, dampak positif bencana dapat terjadi misalnya salah satunya adalah letusan gunung berapi dapat menyuburkan tanah dalam jangka waktu lama (Tribunjogja.com, 2018).

Keberhasilan penanganan bencana alam tidak akan dapat terwujud apabila masyarakat tidak memiliki kemampuan dalam mengelola bencana secara optimal. Artinya, masyarakat merupakan pelaku utama dalam penanganan bencana bukan semata menjadi kewajiban dan tugas pihak luar. Masyarakat dipandang sebagai subjek atau aktor yang dapat berperan serta dalam penanganan bencana dengan memanfaatkan segala kapasitas yang dimilikinya (Takeuchi, Mulyasari, \& Shaw, 2011). Sebagai subjek, tentu masyarakat dapat menggunakan segala kemampuan dan potensi yang dimiliki dalam menyiapkan dan merespons bencana, dan memperbaiki dampak bencana yang terjadi dan sekaligus memanfaatkan kearifan lokal. Salah satu kemampuan masyarakat yaitu kemampuan dalam bentuk pendayagunaan modal sosial yang berkembang dalam kehidupan. Modal sosial merupakan salah satu unsur penting untuk membangun masyarakat tahan bencana dan sebagai suatu energi sosial yang dapat dimanfaatkan untuk membangun ketahanan masyarakat terhadap bencana. Modal sosial merupakan suatu kapasitas yang dimiliki masyarakat sendiri dan kepemilikannya sebagai wujud energi sosial perlu dioptimalkan (Korten, 1986). Modal sosial merupakan suatu potensi yang perlu dipahami, dikembangkan, dan dijaga agar memberikan manfaat positif dalam kehidupan bermasyarakat.

Modal sosial sendiri dimaknai sebagai sumber daya baik nyata maupun potensi yang dicapai dari suatu hubungan (Coleman, 1988). Modal ini terbentuk karena interaksi terusmenerus antar individu yang menghasilkan saling tukar informasi, nilai, dan pengetahuan bermanfaat pada individu-individu. Relasi ini menghasilkan koneksitas antara individu, jaringan sosial, dan norma resiproksiti dan kepercayaan (Putnam, 2000). Modal ini merupakan koneksi yang dimiliki masyarakat baik terhadap diri mereka sendiri, tetangga, maupun dan hal-hal lain dalam masyarakat secara keseluruhan. Ini merujuk pada jaringan yang mempengaruhi aktivitas ekonomi dan sosial, kepercayaan, dan norma sosial dalam masyarakat, menciptakan ikatan-ikatan yang lebih kuat di masyarakat (Grootaert \& van Bastelaer, 2002). Lebih rinci, modal sosial memiliki tiga unsur di dalamnya yaitu: structural, relasi, dan kognisi. Dimensi struktur mencakup mekanisme hubungan antarpara pelaku. Dimensi relasi mencakup jejaring yang terbangun di antara para pelaku. Sedangkan dimensi kognisi mencakup kepercayaan, nilai, obligasi, dan komitmen (Nahapiet \& Ghoshal, 1998).

Kehadiran modal sosial mampu menghasilkan manfaat produktif bagi kehidupan. Modal sosial memberikan manfaat ekonomi dan sosial baik terhadap individu-individu yang terlibat maupun terhadap pihak lain seperti tumbuh solidaritas, kemudahan akses informasi, difusi informasi, terbentuk masyarakat sivil, dan kebersamaan dalam menyelesaikan tugas sosial (Adler \& Kwon, 2000). Woolcock (1998) memberikan pemisahan yang berguna mengenai bagaimana modal sosial berfungsi dalam kehidupan. Menurutnya, modal sosial memiliki tiga fungsi, yaitu: (a) bonding, yaitu ikatan antarindividu dalam situasi yang sama seperti keluarga dekat, teman akrab, dan tetangga, (b) bridging meliputi ikatan yang lebih longgar dari beberapa orang seperti teman jauh dan rekan sekerja, dan (c) linking, yang berfungsi menjangkau orang-orang yang berbeda pada situasi yang berbeda seperti individu-individu di luar komunitas yang dapat mendorong anggota komunitas memanfaatkan banyak sumber daya dari luar komunitasnya (Field, 2005).

Ironisnya adalah pemahaman terhadap peran strategis modal sosial dalam upaya mengembangkan masyarakat sadar bencana belum berkembang dalam kehidupan masyarakat. Beberapa faktor penyebabnya yaitu pertama, potensi-potensi masyarakat sebenarnya banyak tersimpan namun karena pendekatan pengembangan masyarakat "top down" yang lebih memposisikan pihak pemberi intervensi memiliki kewenangan lebih besar dibanding pihak penerima intervensi yang dipandang kurang mampu mengatasi masalah secara 
mandiri sehingga akhirnya mereka dipandang perlu diberdayakan (Friedmann, 1992; Sumarno \& Suryono, 2014), kedua, dalam tataran teknis pengembangan masyarakat sadar bencana sudah banyak dilakukan oleh berbagai pihak namun masih belum terbangun sinergitasnya sehingga apa yang disebut dengan jaringan pemberdayaan belum terbangun (Glichrist, 2009), dan ketiga, secara empiric ditemukan kegiatan pendidikan dalam rangka menciptakan manusia yang tanggap bencana dominan difokuskan pada peningkatan kompetensi human capital dalam kebencanaan seperti pelatihan penanganan korban bencana, pelatihan trauma healing, diteksi awal bencana, pelatihan evaluasi korban, dan dsb. dibanding dengan penguasaan atau pengembangan kompetensi modal sosial (Widodo, Widowati, \& Suyoso, 2014; Ayriza, 2011). Oleh karenanya, diperlukan pengembangan kompetensi modal sosial (Neace, 1999) bagi masyarakat rawan bencana.

Modal sosial sebagai suatu sumber daya produktif yang memberikan manfaat pada individu dan kolektif (Kilpatrick, Field, \& Falk, 2003) sangat diperlukan dalam membangun masyarakat yang memiliki resiliensi terhadap bencana. Penelitian yang dilakukan Bowen (2009) menunjukkan modal sosial mendukung usaha-usaha yang dilakukan dalam melindungi lingkungan alam yang mendukung kemaslahatan manusia, dengan mengembangkan: (i) koneksi sosial (social connection) yang dapat memotivasi individu dan mengembangkan tindakan mayarakat, dan (ii) menjamin isu-isu perubahan lingkungan dan dampak kelestariannya dapat dipertimbangkan dalam suatu keintegrasian lintas segmen-segmen kebijakan pemerintah. Aldrich \& Meyer (2015) juga menunjukkan modal sosial dalam bentuk bridging dan bonding mampu mengembangkan ketahanan masyarakat misalnya ikatan sosial mempermudah penyampaian informasi kebencanaan kepada warga masyarakat, saling mendukung, dan mempermudah penyampaian bantuan, dan memudahkan memperoleh dukungan dari luar untuk perbaikan pasca bencana karena terbangun bridging social capital.

Lebih detail, urgensi modal sosial dalam penanganan bencana dicirikan dengan manfaat yang dihasilkannya sebagaimana dikemukakan Wood, Boruff \& Smith (2013) pada tabel 1. Modal sosial dapat mengurangi isolasi sosial, mendukung tindakan bersama dan solidaritas, mengembangkan kesejahteraan psikologis, dan menciptakan kohesivitas dan kebersamaan masyarakat.

Mendasarkan pemikiran di atas, penelitian ini bertujuan memahami bagaimana peran modal social dalam penanggulangan bencana masyarakat rawan bencana termasuk dalam kawasan gunung Merapi dalam konteks membangun masyarakat berdaya dan memiliki ketahanan terhadap bencana. Pemahaman yang tepat mengenai kebencanaan pada masyarakat ini diharapkan memberikan kontribusi positif pada pengelolaan pemberdayaan masyarakat berbasis pendayagunaan modal sosial guna tercapai kehidupan masyarakat yang sejahtera.

\section{METODE}

Penelitian ini merupakan penelitian studi kasus yaitu dimaksudkan untuk memahami secara mendalam fenomena yang ada di masyarakat (Yin, 2015). Penelitian ini dilakukan pada Desa Girikerto, Kecamatan Turi, Sleman, Daerah Istimewa Yogyakarta. Pemilihan desa ini dilakukan secara purposive yaitu sebagai desa yang rentan terdampak letusan Gunung Merapi dan atas mempertimbangkan informasi resmi yang dikeluarkan oleh Badan Penanggulangan Bencana Daerah (PBPD) DIY mengenai wilayah yang sering mengalami bencana alam baik kebakaran, banjir, angin puting beliung, longsor, dan gempa bumi.

Pengumpulan data dilakukan dengan menggali informasi dari para informan yang memiliki keterlibatan dan/atau peran penting dalam usaha penanggulangan bencana alam. Dalam pengumpulan data ini, instrument penelitian ini adalah peneliti sendiri dibantu dengan beberapa orang tenaga pengumpulan data. Peneliti menggunakan pedoman wawancara dan observasi yang disusun mendasarkan pada focus penelitian yaitu peran dimensi modal sosial dalam masyarakat rawan bencana erupsi Merapi. Pedoman divalidasi dengan meminta pendapat teman sejawat sebagai ahli yang relevan dengan focus penelitian. 
Tabel 1. Karakteristik Modal Sosial dalam Bencana

\begin{tabular}{|c|c|}
\hline Aspek & Deskripsi \\
\hline $\begin{array}{l}\text { Proses komunikasi informal dan } \\
\text { formal serta jaringan }\end{array}$ & $\begin{array}{l}\text { Suatu 'grapevine informal" dimana difusi inovasi dalam melengkapi, } \\
\text { melegitimasi, atau mengganti mekanisme formal ketika dibutuhkan. }\end{array}$ \\
\hline $\begin{array}{l}\text { Modal sosial bonding, bridging dan } \\
\text { linking yang kuat }\end{array}$ & $\begin{array}{l}\text { Modal sosial sangat kuat ketika ada dalam semua bentuknya, dan } \\
\text { perbedaan tipe modal sosial memerankan peran berbeda dalam } \\
\text { pengelolaan bencana (ikatan bonding sebagai contoh bertindak baik } \\
\text { sebagai suatu sarana untuk desiminasi informasi dan dukungan } \\
\text { emosional, namun tidak menyediakan sumber daya hubungan } \\
\text { eksternal atau orang berpengaruh yang memfasilitas recovery lebih } \\
\text { cepat. }\end{array}$ \\
\hline $\begin{array}{l}\text { Mekanisme untuk mengidentifikasi } \\
\text { dan menyelamatkan mereka yang } \\
\text { rentan }\end{array}$ & $\begin{array}{l}\text { Sistem untuk menjamin orang-orang yang secara sosial atau geografis } \\
\text { terisolasi dan yang tidak terakses. }\end{array}$ \\
\hline $\begin{array}{l}\text { Kepemimpinan lokal formal dan } \\
\text { informal }\end{array}$ & $\begin{array}{l}\text { Pemimpin lokal terpercaya dengan jejaring baik dan hubungan lintas } \\
\text { sektor dalam masyarakat }\end{array}$ \\
\hline $\begin{array}{l}\text { Organisasi lokal, keterlibatan dan } \\
\text { partisipasi kolektif masyarakat }\end{array}$ & $\begin{array}{l}\text { Suatu level keterlibatan dalam organisasi-organisasi masyarakat } \\
\text { dimana jaringan sosial dikembangkan dan modal sosial dibangun } \\
\text { yang dapat dilakukan sesuai waktu yang ditentukan. Keterlibatan } \\
\text { masyarakat membentuk kesamaan tempat, visi, dan kepemilikan } \\
\text { bersama. }\end{array}$ \\
\hline Kepercayaan pada orang lain & $\begin{array}{l}\text { Suatu tingkat keterpercayaan dalam tindakan dan pengetahuan dari } \\
\text { para pemimpin lokal dan anggota masyarakat. }\end{array}$ \\
\hline $\begin{array}{l}\text { Solidaritas yang lahir melalui berbagi } \\
\text { pengalaman }\end{array}$ & $\begin{array}{l}\text { Visi yang sama yang berasal dari tindakan kolektif dalam merespon } \\
\text { goncangan sistemik. }\end{array}$ \\
\hline $\begin{array}{l}\text { Pemahaman peran modal sosial dan } \\
\text { proses-proses sosial }\end{array}$ & $\begin{array}{l}\text { Pengakuan mengenai sumber daya masyarakat oleh kewenangan } \\
\text { internal dan eksternal selama semua fase siklus pengelolaan bencana }\end{array}$ \\
\hline
\end{tabular}

Informan penelitian ini adalah para kepala dukuh sebagai tokoh masyarakat, ketua organisasi pemuda, aparat pemerintah desa, dan anggota kelompok swadaya masyarakat bidang kebencanaan yang berada di desa yang dikaji. Untuk menggali informasi yang dibutuhkan, wawancara kepada para informan dilakukan sesuai kesepakatan baik waktu pelaksanaan maupun tempat wawancara. Focus group discussion dengan aparat pemerintah dan para kepala dukuh pun dilakukan bertempat di balai desa setempat sesuai kesepakatan peneliti dan pihak desa. Selain itu, observasi dilakukan terhadap aktivitas penanggulangan bencana yang ada di desa tersebut serta kondisi alam yang menunjukkan potensi bencana.

Data yang diperoleh dianalisis menggunakan teknik analisis data kualitatif yaitu melalui tahapan kondensasi data, penyajian data dan penarikan kesimpulan (Miles, Huberman, \& Saldana, 2014). Untuk menjamin keabsahan data kualitatifini dilakukan triangulasi dan perpanjangan pengamatan. Triangulasi dilakukan untuk mengecek keabsahan data yang terkumpul, yaitu mengecek data hasil wawancara dengan observasi, dan/ atau dengan dokumentasi dan dengan mengecek data berdasarkan sumber informan yang memberikan data. Perpanjangan pengamatan dilakukan untuk lebih dalam memperoleh informasi mengenai kegiatan pemanfaatan modal sosial dalam kehidupan masyarakat sehari-hari dan aktivitas penanganan kebencanaan yang dilakukan di masyarakat.

\section{HASIL DAN PEMBAHASAN Hasil}

Hasil penelitian dapat dikemukakan berikut ini sesuai dengan fokus penelitian yang meliputi: potensi bencana yang ada dan pemanfaatan modal sosial dalam konteks mitigasi bencana pada desa yang diteliti. 


\section{Desa Girikerto Rawan Erupsi Merapi}

Girikerto adalah sebuah desa di Kecamatan Turi, Kabupaten Sleman, Provinsi Daerah Istimewa Yogyakarta, Indonesia. Pada awalnya Desa Girikerto merupakan wilayah yang terdiri dari empat kelurahan yakni Kelurahan Tanggung, Ngandong, Nangsri Lor dan Kemirikebo. Desa Girikerto, Kecamatan Turi, Kabupaten Sleman berada di lereng gunung Merapi. Desa ini berjarak sekitar $12 \mathrm{~km}$ terhadap puncak gunung Merapi dan termasuk dalam zona bahaya bencana erupsi Merapi. Desa Girikerto memiliki luas sekitar $13.07 \mathrm{~km}^{2}$ dengan jumlah penduduk 7.712 jiwa yang terbagi dalam 13 padukuhan. Batas wilayah desa ini yaitu sebelah utara berbatasan langsung dengan Gunung Merapi, sebelah timur berbatasan dengan Desa Purwobinangun Kec. Pakem, sebelah selatan berbatasan dengan desa Donokerto, dan sebelah barat berbatasan dengan Desa Wonokerto (Pemerintah Desa Girikerto, 2017).

Dilihat dari aspek potensi ekonomi, wilayah Desa Girikerto merupakan wilayah agraris yang subur sehingga tak heran apabila hampir semua penduduk memiliki aktivitas mengolah lahan pesawahan dan berkebun. Dalam aktivitas ini, tanaman yang menjadi komoditas utama yang dihasilkan warga masyarakat desa ini yaitu buah salak pondoh (salacca edulis reinw) dan padi. Buah-buahan lain juga tumbuh dengan subur di wilayah ini. Selain itu, banyak warga masyarakat yang memelihara kambing etawa sebagai sumber mata pencaharian khususnya warga masyarakat Dusun Nganggring. Peternakan kambing sangat potensial dikembangkan di wilayah desa ini karena letak geografis dan lingkungan alam menyediakan makanan berlimpah bagi ternak kambing. Pada aspek social-budaya, beragam aktivitas seni-budaya berkembang di kehidupan masyarakat. Misalnya, di desa ini dikembangkan secara rutin tradisi kirab yaitu Budaya ngrowod atau Ngleluri Ombyaking Warga Hametri Kuncara Desa yang merupakan rangkaian kegiatan bersih desa untuk mensyukuri karunia dari Tuhan, dan aktivitas sosial-budaya lainnya seperti pentas seni, dialog budaya, lomba kesenian dan pengajian (Pemerintah Desa Girikerto, 2017).

Desa Girikerto merupakan salah satu wilayah yang terletak di penghujung utara wilayah Provinsi Daerah Istimewa Yogyakarta. Sebagai wilayah yang berada di bawah (kaki gunung) Merapi tidak dapat dipungkiri bahwa desa ini merupakan wilayah yang rentan terdampak bencana erupsi Merapi. Walaupun demikian, sebagian besar wilayahnya memiliki tanah yang subur dan dapat dikelola oleh masyarakat untuk aktivitas perkebunan dan pertanian. Gunung Merapi merupakan salah satu gunung paling aktif yang ada di Indonesia dengan ketinggian mencapai sekitar $3 \mathrm{Km}$. Jarak antara puncak Merapi dan desa Girikerto hanya $12 \mathrm{Km}$ sehingga menjadikan wilayah desa ini masuk kategori daerah rawan bencana erupsi Merapi (BPBD Yogyakarta, 2017).

Bencana erupsi Merapi merupakan bencana yang sangat mengerikan bagi masyarakat. Hal ini terlihat dari dampak negative erupsi Merapi terhadap kehidupan masyarakat dalam aspek ekonomi, kesehatan, dan sosial. Erupsi Merapi yang menimbulkan abu vulkanik menyebabkan penderitaan, kematian, dan kerusakan lahan lingkungan desa Girikerto. Pada aspek ekonomi, erupsi Merapi yang terjadi tahun 2010 misalnya telah menyebabkan ribuan hektar tanaman salak pondoh hancur sehingga gagal panen karena tertimbun abu vulaktif Gunung Merapi, matinya ratusan hewan ternak seperti kambing dan sapi akibat terhempas oleh asap panas gunung Merapi, dan berbagai kerusakan lingkungan lainnya (Rahayu, Ariyanto, Komariah, Hartati, Syamsiyah, \& Dewi, 2014). Kejadian ini diungkapkan pula oleh ketua dukuh Sengon bahwa bencana alam erupsi Merapi telah menyebabkan ternak-ternak warga mati terpapar awan panas bahkan menyebabkan korban jiwa dari warga dusunnya seperti yang terjadi pada erupsi Merapi tahun 2010. Bahkan ia pun menceritakan musibah yang sangat mengerikan yaitu bagaimana awan panas mengempas puluhan warga masyarakat yang sedang melaksanakan kegiatan matenan di salah satu dusun pada 22 November 2004. Dampak sosial erupsi ini pun nampak dalam bentuk kehancuran insfrastruktur sosial seperti sarana dan prasarana pendidikan yang menimbulkan kesulitan bagi anak-anak untuk mengakses layanan pendidikan. Sedangkan dampak kesehatan diwujudkan dalam bentuk terjadi trauma mendalam bagi warga masyarakat yang terkena dampak erupsi Merapi dan kemunculan penyakit misalnya terganggu saluran pernafasan, kulit, dan cacat fisik.

Erupsi Merapi selain memberikan dampak negative juga tidak dipungkiri memberikan 
manfaat positif bagi warga masyarakat. Manfaat ini muncul setelah bencana ini terjadi. Lahar dingin yang terdapat di sungai yang berhulu pada gunung Merapi seperti Kali Krasak, Kali Gendol, dan Kali Putih menyebabkan melimpahnya pasir alam yang sangat berguna bagi proses pembangunan infrastruktur. Keberadaan pasir telah menjadikan muncul aktivitas ekonomi pertambangan misalnya adanya usaha depo pasir dan jasa angkut material. Selain ini, abu vulkanik yang dihasilkan lama-kelamaan menjadi tanah yang sangat subur untuk pertanian.

\section{Modal Sosial dalam Penanganan Bencana}

Hasil penelitian mengenai modal sosial sebagai suatu hal positif yang dihasilkan dari relasi sosial perlu dipahami dan dikelola dalam rangka mengembangkan masyarakat yang siap dan mampu mengantisipasi kemungkinan terjadi bencana dan resikonya. Berikut ini deskripsi peran modal sosial dalam penanganan bencana di desa Girikerto yang meliputi dimensi nilai dan norma, komitmen, kepercayaan, relasi sosial, dan berbagi pengetahuan.

\section{Nilai dan Norma}

Nilai dan norma yang berkembang di masyarakat Girikerto dalam konteks mengantisipasi bencana alam yang terjadi yaitu nilai saling membantu sesama, nilai kebersamaan, dan nilai melestarikan alam. Nilai saling membantu sangat berkembang di warga masyarakat yang mana perwujudkan nilai ini terdapat dalam aktivitas bersama yaitu aktivitas membangun rumah seorang warga masyarakat dalam proses pembangunan rumah baik rumah tradisional maupun rumah yang sudah berpola modern. Pekerjaan membangun rumah dilakukan bersama-sama terutama pada warga masyarakat yang masih dipandang termasuk warga masyarakat kurang beruntung. Warga masyarakat memberikan bantuan sesuai kemampuannya terutama dalam hal bantuan tenaga. Selain membangun rumah, aktivitas kebersamaan pun diwujudkan dalam kegiatan sosial-keagamaan yaitu pelaksanaan kenduri. Kenduri merupakan tradisi yang berkembang di masyarakat Girikerto baik dalam rangka memperingati peristiwa tertentu misal memperingati hari kelahiran tokoh agama, merti dusun, dan perayaan selamatan yang dilakukan oleh salah satu keluarga. Selain gotong royong dan kenduri, kedua nilai tersebut terwujud dalam bentuk adanya memberikan sumbangan baik dalam acara rewangan maupun dalam kegiatan sripahan dan pembangunan resepan air secara bersama-sama di masing-masing wilayah dusun yang berfungsi untuk menekan terjadi kebanjiran dan mempercepat penyerapan air hujan agar tidak terjadi kelangkaan air tanah.

Norma yang berkembang dalam mengontrol nilai di masyarakat yaitu normanorma yang bersifat laten. Norma ini diwujudkan dalam perilaku warga masyarakat yaitu apabila ada warga masyarakat yang dipandang tidak mau ikut terlibat dalam aktivitas bersama, warga masyarakat lain akan bertindak membiarkan apabila warga masyarakat tersebut memiliki aktivitas yang membutuhkan pelibatan warga lain. Artinya, dalam masyarakat Girikerto berkembang kesepakatan bersama bahwa apabila seorang warga tidak mau turut bersama dalam kegiatan sosial, maka warga lainnya cenderung akan membiarkan atau tidak membantu apabila ia memiliki kepentingan. Tindakan ini bertujuan sebagai sanksi dan penyadaran pada individu agar merasakan sendiri bagaimana rasanya tidak ada bantuan orang lain. Namun sebelumnya, para tokoh masyarakat dalam acara-acara tertentu misalnya pertemuan rukun tetangga atau forum lainnya mengingatkan untuk tetap menjaga kebersamaan dalam kehidupan bermasyarakat dan tetap mengajak pihak-pihak yang dipandang masih berbeda untuk tetap terlibat dalam aktivitas bersama. Dalam hal ini, budaya homogen dalam aktivitas sosial-budaya sangat ditekankan di Wilayah Girikerto.

\section{Komitmen}

Komitmen pun dikembangkan dalam kehidupan masyarakat Girikerto dalam rangka membangun kesiapsiagaan menghadapi bencana. Untuk mencegah kebakaran hutan di lereng Merapi, terutama pada masyarakat yang berada di wilayah atas yang dekat dengan taman nasional, dikembangkan komitmen bersama yaitu kesepakatan dalam penggunaan pupuk untuk tanaman baik pepohonan maupun tanaman salak. Setiap warga dianjurkan tidak menggunakan pupuk kimia namun pupuk alami dalam proses pemupukan. Penggunaan pupuk alami dipandang mampu menguatkan pohon atau tanaman untuk tetap hidup ketika terjadi musim kemarau dibanding dengan penggunaan pupuk 
kimia. Komitmen bersama pun diwujudkan dalam bentuk aktivitas memperingati tradisi adat-istiadat yang sudah berkembang lama di masyarakat yaitu misalnya merti dusun dan peringatan hari kemerdekaan. Menurut kepala desa, kegiatan merti dusun dilaksanakan setiap tahun sebagai bentuk wujud terima kasih kepada para pendahulu yang sudah berusaha memelihara kelangsungan kehidupan desa dan sebagai upaya melestarikan kearifan lokal masyarakat Girikerto yang memperkaya budaya Yogyakarta.

\section{Kepercayaan}

Kepercayaan yang berkembang di masyarakat Girikerto umumnya bersifat umum yaitu terbangun atas keyakinan bahwa apabila perilaku seseorang baik di kehidupan masyarakat, maka kebaikan akan ia peroleh. Sebaliknya apabila ia bertindak buruk dalam kehidupan maka keburukan dalam menimpa dirinya. Dalam konteks kebencanaan, kepercayaan yang dibangun oleh warga masyarakat dalam upaya mengantisipasi atau mengurangi dampak bencana sosial adalah tindakan pemberian sanksi sosial terhadap warga masyarakat yang melanggar norma sosial khususnya perilaku kenakalan remaja dan kriminalitas.

Kepercayaan dalam pengantisipasian bencana alam pun ditemukan dalam hal keberadaan kelompok pengelola air di dusun Ngandong. Dusun ini secara geografis memiliki ketinggian tanah relatif tinggi dibandingkan dusun lainnya. Di dusun ini, pemanfaatan air mengandalkan ketersediaan air yang diperoleh dari hulu sungai yang ada di kawasan hutan lindung Taman Nasional Gunung Merapi. Melalui pipa-pipa, air disalurkan ke rumahrumah penduduk, yang sebelumnya air ditampung dalam bak penampungan pada titiktitik tertentu. Setiap keluarga membayar dana sebesar Rp5.000,00 untuk biaya pemeliharaan pipa dan operasional pengelolaan air. Dalam hal inilah, dana dikelola sepenuhnya oleh pengurus yang tergabung dalam kelompok "Tirta Lestari". Pengelolaan dana untuk kepentingan tersebut tidak dijadikan sebagai persoalan oleh para pengurus, para dukuh dan warga masyarakat setempat.

Bentuk kepercayaan yang lain yaitu kepatuhan warga masyarakat Girikerto terhadap mekanisme penanganan bencana. Apabila terjadi erupsi Merapi, para warga masyarakat diminta mematuhi perintah dari kepada desa sebagai koordinator Desa Tangguh Bencana. Seperti pada bencana erupsi Merapi pada tahun 2010, warga masyarakat secara umum mengikuti petunjuk dan perintah koordinator Desa Tangguh Bencana. Menurut aturan ini, apabila terjadi erupsi Merapi warga masyarakat diharuskan berkumpul di titik pengungsian yang salah satunya adalah di depan desa Girikerto setelah diinstruksikan bahwa level erupsi sudah mencapai level awas. Adanya kepatuhan warga ini, memudahkan proses evakuasi warga masyarakat terutama mereka yang rentan yaitu orang tua lansia, ibu-ibu hamil, dan anak-anak seperti terjadi pada erupsi Merapi tahun 2010.

\section{Relasi Sosial}

Relasi sosial yang terjalin dalam rangka pencegahan dampak resiko bencana dilakukan secara informal dan formal. Komunikasi antardukuh, dukuh dengan aparat desa, dan aparat desa dengan instansi pemerintah lokal dilakukan secara formal melalui mekanisme persuratan, pertemuan rutin dan komunikasi menggunakan sarana telepon. Komunikasi antarpara dukuh, dan para dukuh dengan aparat desa dilakukan dalam forum pertemuan rutin yang dilakukan di Balai Desa Girikerto. Pertemuan ini merupakan sarana untuk mendiskusikan berbagai permasalahan yang dihadapi warga masyarakat termasuk dalam penanganan bencana alam yang dihadapi setiap pedukuhan dan membahas mengenai pelaksanaan kegiatan pembangunan di wilayah Girikerto. Pertemuan dilakukan setiap bulan sekali tepatnya pada hari Kamis. Dengan instansi pemerintah lokal, para dukuh dan aparat desa berhubungan secara formal yang diwujudkan dalam bentuk tindakan rapat koordinasi untuk membahas berbagai permasalahan yang terjadi di masyarakat dan termasuk mengenai desa siaga bencana walau dilakukan secara insidental. Sedangkan, para dukuh berkomunikasi secara informal di antara mereka dalam berbagai kesempatan di kehidupan masyarakat misalnya pada saat bertemu dalam kegiatan kenduren, sripahan, sambatan, dan aktivitas sosial lainnya. Sering dalam pertemuan ini mereka membicarakan berbagai persoalan kebencanaan dan masalah lainnya.

Relasi dengan pihak luar yaitu dengan desa lain terbangun pula dalam rangka mengantisipasi dampak erupsi Merapi terutama terhadap 
keselamatan penduduk dan keberlanjutan pendidikan formal anak-anak yang menjadi korban bencana. Setelah erupsi Gunung Merapi tahun 2010 yang menyebabkan berbagai dampak negatif yang salah satunya yaitu terdapat kesulitan anak-anak usia sekolah yang ingin bersekolah selama periode pengungsian, pemerintah desa mengembangkan kerja sama dengan sekolah yang ada di seluruh desa di wilayah kecamatan Turi. Kerja sama ini disebut sebagai sister school. Sister school dibentuk untuk memberikan kemudahan kepada anakanak pengungsi untuk memasuki kembali ke sekolah apabila sekolah awal mereka terkena dampak erupsi Merapi. Selain kerja sama sister school, pemerintah desa pun mengembangan kerja sama dengan semua desa di wilayah Turi dalam bentuk kegiatan yang disebut sister village atau desa kembar, yang tujuan utamanya yaitu membangun keswadayaan desa yang tidak terdampak untuk dapat memberikan fasilitas pengungsian, bantuan, penampungan, dan fasilitas lainnya terhadap para korban bencana erupsi Merapi. Kedua program ini merupakan inisiatif instansi pemerintah lokal yaitu Badan Penanggulangan Bencana Daerah (BPBD) Kabupaten Sleman.

\section{Sharing Pengetahuan}

Pengetahuan mengenai kebencanaan, terutama bencana gunung Merapi, terjadi melalui kesempatan-kesempatan sosial yang ada di lingkungan masyarakat seperti pertemuan RT, dasa wisma, dan pertemuan rutin para dukuh. Misalnya, pada pertemuan rutin pengurus RT, merti dusun, dan rewangan rumah, kepala dukuh sering menyampaian permasalahan kebencanaan yang ada di lingkungan masyarakat. Misalnya, kepala dukuh sering menyampaikan kepada pengurus RT untuk mengajak warga masyarakat agar mau membersihkan lingkungan sekitar, membangun resapan-resapan air, membuang sampah pada tempatnya, dan mengingatkan untuk saling membantu antarwarga.

Pertemuan antardukuh dilakukan baik rutin setiap sebulan bawah koordinasi kepala desa sekali maupun dengan saling berkomunikasi secara informal. Dalam pertemuan rutin dukuh yang bertempat di balai desa, sering disampaikan mengenai bagaimana menyiapkan warga masyarakat untuk lebih siap dalam menghadapi bencana. Misalnya, apabila ada program mengenai program penanganan bencana dan program pengembangan desa lainnya yang bersumber dari pemerintahan kabupaten dan instansi pemerintah lainnya, para dukuh akan diajak bermusyawarah mengenai teknis pelaksanaan misal mengenai program school sister yang merupakan ide BPBD Kabupaten Sleman. Para dukuh pun secara informal dalam kehidupan sehari-hari sering bertukar pengalaman satu dengan lainnya. Misalnya, ketika ada tanda-tanda alam yang menunjukkan bahwa gunung Merapi sudah berpotensi meletus, dukuh yang mengetahuinya terlebih dahulu akan menginformasikan kepada dukuh lain. Tanda alam pun kadang dapat bersifat irasional seperti disampaikan oleh dukuh Ngandong, walau oleh para dukuh yang lain hal ini tidak dapat diterima secara rasional. Proses ini dilakukan karena para dukuh secara langsung berkewajiban menyampaikan informasi mengenai kebencanaan kepada dukuh dan pemerintah desa sebagai bentuk keaktifan dalam komunitas tanggap bencana (Tagana) yang dibangun di desa Girikerto.

Pengetahuan dan informasi kebencanaan lainnya diperoleh dari kegiatan pelatihan yang diselenggarakan oleh BPBD. BPBD sebagai lembaga yang bertugas untuk menjadikan individu dan warga masyarakat tangguh terhadap bencana memberikan kegiatan pendidikan dan pelatihan kepada warga masyarakat yang sangat sering dalam waktu setahun. Pelatihan umumnya terkait dengan peningkatan pemahaman warga masyarakat mengenai bagaimana mekanisme pengurusan logistik di wilayah bencana, titik kumpul pengungsian, produksi makanan di dapur umum, penggunaan jalur evakuasi, dan penanganan korban bencana. Pengetahuan tersebut selanjutnya oleh para warga yang dilatih akan disebarluaskan kepada warga masyarakat lainnya terutama pada tokoh masyarakat dan anggota Tagana dengan berkomunikasi secara formal dan informal.

Ringkasan mengenai peran modal sosial dalam penanganan bencana khususnya erupsi Merapi ditunjukkan pada Tabel 2.

\section{Manfaat Modal Sosial dalam Penanganan Bencana}

Apabila dilihat dari kebermanfaatan modal sosial sesuai dengan terjadi bencana yaitu sebelum, ketika, dan setelah bencana, 
hasil penelitian pada desa tersebut menunjukkan pemanfaatan modal sosial lebih dominan dilakukan sebelum terjadi bencana. Aktivitas bersama warga masyarakat Girikerto seperti pembuatan resapan air, penggunaan pupuk alami, kesepakatan tentang sister village dan school sister, dan pembuatan aturan mekanisme evakuasi dimaksudkan untuk mencegah dampak negatif baik secara langsung maupun tidak langsung. pemenuhan kebutuhan hidup setelah pasca bencana belum terbangun. Apabila terjadi letusan Merapi, biaya pemenuhan kebutuhan selama di wilayah pengungsian mengandalkan harta benda sendiri atau ragat dewe, dan dari bantuan pemerintah atau masyarakat. Tabel 3 menunjukkan manfaat modal sosial yang ada di kedua desa yang diteliti.

Pemanfaatan modal sosial seperti dikemukakan di atas, memberikan manfaat yang

Tabel 2. Dimensi Modal Sosial dalam Bencana

\begin{tabular}{ll}
\hline Dimensi & Wujud Aktivitas \\
\hline Nilai dan norma & - Gotong-royong \\
& - Perilaku saling membantu \\
& - Kebersamaan \\
& - Pemberlakuan sanksi sosial \\
& - Pengaturan penggunaan pupuk tanaman salak \\
& - Peringatan tradisi merti dusun \\
& - Sanksi sosial/general trust \\
Komitmen & - Keterbukaan usaha bersama manajemen air \\
& - Kepatuhan pada aturan perintahan desa \\
Kepercayaan & - Komunikasi informal dan formal \\
& - Pertemuan rutin antardukuh tingkat desa \\
& - Rapat koordinasi jajaran desa \\
& - Sister school \\
& - Sister villager \\
& - Pertemuan rutin warga \\
& - Pertemuan antar dukuh \\
& - Tukar pengalaman secara informal \\
& - Diklat dari BPBD dan PT \\
&
\end{tabular}

Tabel 3. Manfaat Modal Sosial dalam Penanganan Bencana

\begin{tabular}{ll}
\hline Fungsi Modal Sosial & Manfaat yang Dicapai \\
\hline Bonding & - Kepedulian sosial \\
& - Kekeluargaan \\
& - Sumbangan material \\
& - Penyebaran informasi penanganan bencana cepat \\
Bridging & - Kemudahan evakuasi dengan sister village \\
& - Keberlanjutan pendidikan anak dengan sister village \\
& - Mekanisme penanganan bencana tersentral \\
& - Penyebaran informasi penanganan bencana cepat \\
Linking & - Peningkatan pengetahuan sadar bencana \\
\hline
\end{tabular}

Namun, pada desa ini pemanfaatan modal sosial yang diperuntukkan untuk meminimalkan kerugian terutama dalam aspek ekonomi atau positif terhadap kesiapan warga masyarakat dalam mengantisipasi dan menangani bencana. Walau diketahui bahwa perilaku mengutamakan 
kepentingan sendiri dan orientasi materialistik, dan penyalahgunaan wewenang dapat menghancurkan keberfungsian modal sosial di masyarakat.

\section{PEMBAHASAN}

Potensi bencana yang dominan terjadi pada desa Girikerto yaitu bencana letusan Gunung Merapi. Walau akhir-akhir ini bencana kekeringan dan banjir sudah mulai dirasakan warga masyarakat. Kehadiran bencana erupsi Merapi memberikan dampak negatif terhadap kehidupan masyarakat seperti menimbulkan kerusakanlingkungan, permukinan, dankematian. Apabila dilihat akibat negatifnya, pengalaman menunjukkan bencana letusan Gunung Merapi dipandang sangat membahayakan. Bencana ini bagi warga masyarakat Girikerto dipandang sebagai sesuatu yang akan tetap ada, dan tidak dapat dihilangkan, namun hanya perlu diantisipasi. Hal ini menunjukkan masih tetap dibutuhkan tindakan edukatif untuk membangun pengetahuan, sikap, dan keterampilan individu dan/atau masyarakat agar memiliki kesadaran, sikap, pengetahuan, dan keterampilan mengenai potensi dan resiko bencana yang terjadi (Duffy, 2008; Selby \& Kagawa, 2012).

Agar masyarakat Girikerto tidak terdampak besar oleh bencana alam erupsi Merapi, kemampuan atau daya tahun resiliensi harus dikembangkan. Resiliensi dimaknai sebagai kemampuan masyarakat dan sistem biofisik/ lingkungan untuk bertahan atau meredam bencana alam, secara cepat memperbaiki dampak bencana, dan mengurangi kerentanan di masa depan melalui strategi adaptif (Masterson, Peacock, Van Zandt, Grover, Schwarz, \& Cooper, 2014) Kemampuan ini dapat dikembangkan dengan menekankan pada partisipasi masyarakat di tingkat lokal (UNESCO, 2008; Paton \& Johnston, 2001). Salah satu kemampuan yang dimiliki oleh masyarakat agar memiliki ketahanan terhadap bencana adalah kapasitas mendayagunakan modal sosial yang tumbuh dan berkembang sebagai hasil interaksi social yang berkelanjutan dalam kehidupan sosial. Dengan kata lain, pencegahan dan penanganan bencana sebaiknya dilakukan atas pandangan bahwa masyarakat memiliki energi sosial sebagai potensi yang muncul karena hubungan timbal balik yang ajeg dan menguntungkan dalam kehidupan yaitu apa yang disebut dengan modal sosial (social capital).
Hasil penelitian menunjukkan bahwa pada masyarakat Girikerto modal sosial yang mencakup: nilai dan norma, komitmen, kepercayaan, jejaring, dan sharing pengetahuan/ informasi sudah dapat dimanfaatkan dalam rangka mewujudkan masyarakat yang tahan bencana. Pemanfaatan modal sosial pada desa tersebut lebih cenderung didasarkan oleh motivasi untuk hidup serasi dengan sesamanya. Kehadiran modal sosial disebabkan adanya kebutuhan bersama terutama dalam menciptakan kehidupan yang serasi dengan alam. Pada masyarakat tersebut, modal sosial mampu bermanfaat dalam hal peningkatan kesadaran masyarakat terhadap bencana, peningkatan informasi, dan solidaritas sosial. Hal ini menunjukkan modal social bersifat produktif dalam kehidupan masayarakat (Westlund, 2006).

Apabila dilihat dari fungsi modal sosial yang mencakup: bonding, bridging, dan linking, modal sosial di desa yang diteliti mampu memberikan manfaat pada masyarakat dalam merespons dan menangani bencana. Modal sosial yang bersifat mengikat (bonding) mampu memberikan kontribusi pada peningkatan kepedulian sosial, kekeluargaan, kebersamaan, dan sumbangan material. Bridging social capital mampu memberikan manfaat berupa peningkatan pengetahuan mengenai kebencanaandan perilaku saling membantu, dan linking social capital mampu menghasilkan kebijakan, meningkatkan koordinasi yang baik dalam penanganan bencana, dan peningkatan pengetahuan kebencanaan warga masyarakat. Hasil penelitian ini sesuai dengan penelitian lain bahwa modal sosial berkontribusi positif pada kehidupan masyarakat rawan bencana (Nakagawa \& Shaw, 2004; Hawkins \& Maurer, 2010; Bhandari, 2014; Bankoff, 2015; Sanyal \& Routray, 2016).

Keoptimalan fungsi modal sosial terhadap masyarakat dipengaruhi oleh faktor yang mempengaruhinya misalnya kesamaaan atau beragaman aspek masyarakat baik struktural maupun kultural dan keluasan jaringan yang terbangun. Hasil penelitian menunjukkan bahwa kebermanfaatan modal sosial dalam kehidupan masyarakat sangat dipengaruhi oleh perilaku individu atau kelompok yang dalam berinteraksi dengan sesamanya. Sebagai contoh, perilaku individu yang merusak lingkungan dan mementingkan kepentingan sendiri untuk 
memperoleh keuntungan finansial mampu menyebabkan ikatan sosial menjadi tidak kondusif.

Karena modal sosial dipandang sebagai sesuatu yang produktif dalam mengembangkan masyarakat di wilayah rawan bencana maka diperlukan upaya untuk mengoptimalkan dan mengembangkan modal sosial yang terbangun di masyarakat. Salah satunya yaitu melalui penyelenggaraan kegiatan pemberdayaan masyarakat dengan pendekatan pendidikan yang berbasis pada pendayagunaan modal sosial. Dalam hal ini tindakan pendidikan dapat dilakukan dengan cara berusaha mengoptimalkan dan memanfaatkan modal sosial sebagai substansi pemberdayaan untuk membekali masyarakat agar mengelola bencana sehingga tidak menimbulkan dampak negatif yang besar. Tujuan pendidikan atau pemberdayaan dimaksud yaitu untuk mempercepat pengembangan masyarakat yang memiliki daya tahan terhadap bencana dengan memanfaatan kearifan lokal dan kapasitas masyarakat yang dimilikinya. Hal ini pun didukung dengan temuan penelitian yang mendukung pentingnya pemberdayaan dalam bentuk pendidikan yang berbasis modal sosial yang mana menunjukkan bahwa untuk mengembangkan kapasitas tahan bencana namun masih dominan menggunakan pola pendidikan yang mengutamakan pengembangan kemampuan human capital dan dalam setting persekolahan (Ayriza, 2011; Widodo, et al., 2014), dan pendidikan sadar bencana dapat dilakukan dengan jalur formal dan nonformal (Suhardjo, 2011; Sujarwo, Mulyadi, \& Tohani, 2015).

\section{SIMPULAN}

Penelitian ini menghasilkan temuan bahwa modal sosial memberikan kontribusi positif dalam mengembangkan masyarakat tahan bencana walau keberadaannya tidak disadari dalam kehidupan bermasyarakat. Secara rinci dapat dikemukakan bahwa: (a) nilai dan norma terbangun dalam aktivitas bersama yang dilandasi kebersamaan, saling menolong, dan kepedulian serta mekanisme hukum karma sebagai norma sosial; (b) komitmen terbangun dalam perilaku memelihara tradisi dan lingkungan agar tidak menimbulkan bencana, (c) kepercayaan terbangun dalam bentuk kepatuhan terhadap aturan desa, keterbukaan dalam penyaluran bantuan dan pengelolaan sumber daya air, disertai keberadaan sanksi sosial, (d) jejaring pada terbangun antar pelaku baik melalui akad kerja sama/kesepakatan dan komunikasi informal, dan (d) berbagi pengetahuan mengenai kebencanaan terjadi melalui pendidikan nonformal yang diselenggarakan instansi pemerintah dan pendidikan informal dalam kehidupan bermasyarakat misalnya melalui pertemuan rutin. Berdasarkan temuan ini, pengembangan masyarakat yang menggunakan pendekatan pendidikan untuk membangun resiliensi pada bencana seharusnya dapat dilakukan dengan memanfaatan modal sosial di masyarakat.

\section{UCAPAN TERIMA KASIH}

Penulis mengucapkan terima kasih kepada Universitas Negeri Yogyakarta yang telah membiayai penelitian ini.

\section{DAFTAR PUSTAKA}

Adler, P. S., \& Kwon, S. (2000). Social capital: The good, the bad, and the ugly. In E. Lesser (Ed.), Knowledge and social capital: Foundations and applications (pp. 89-115). Boston, MA: ButterworthHeineman.

Aldrich, D. P., \& Meyer, M. A. (2015). Social capitalandcommunityresilience.American Behavioral Scientist, 59(2), 254-269. doi:10.1177\%2F0002764214550299.

Ayriza, Y. (2011). Peningkatkan keterampilan guru bimbingan konseling dalam pemerolehan kesiapan psikologis siswa menghadapi bencana alam. Cakrawala Pendidikan, 30(2), 230-241. doi:10.21831/ cp.v0i2.4230.

Bankoff, G. (2015). "Lahat para sa lahat" (everything to everybody): Consensual leadership, social capital and disaster risk reduction in a Filipino community. Disaster Prevention and Management, 24(4), 430-447. doi:10.1108/DPM-042014-0063.

Bhandari, R. B. (2014). Social capital in disaster risk management; a case study of social capital mobilization following the 1934 Kathmandu Valley earthquake in Nepal. 
Disaster Prevention and Management, 23(4), 314-328. doi:10.1108/DPM-062013-0105.

Bowen, G. A. (2009). Social capital, social funds and poor communities: An exploratory analysis. Social Politic Administration, 43(3), 245-269. doi:10.1111/j.14679515.2009.00660.x.

BPBD Yogyakarta. (2017). Peta kajian resiko bencana tahun 2016. [Study of disaster mapping risk in 2016]. Yogyakarta: BPBD Yogyakarta.

Coleman, J. S. (1988). Social capital in the creation of human capital. American Journal of Sociology, 94, S94-S120.

Duffy, N. (2008). A new approach to community flood education. The Australian Journal of Emergency Management, 23(2), 3-7.

Field, J. (2005). Social capital and life long learning. Brisboll: The Policy Press.

Friedmann, J. (1992). Empowerment: The politics of alternative development. Oxford: Blackwell Publisher.

Glichrist, A. (2009). The well-connected community: A networking approach to community development. Bristol: The Policy Press.

Grootaert, C., \& Van Bastelaer, T. (2002). The role of social capital in development. New York, NY: Cambridge University Press.

Hawkins, R. L., \& Maurer, K. (2010). Bonding, bridging and linking: How social capital operated in New Orleans following Hurricane Katrina. British Journal of Social Work, 40(6), 1777-1793. doi:10.1093/bjsw/bcp087.

Kilpatrick, S., Field, J., \& Falk, I. (2003). Social capital: An analytical tool for exploring lifelong learning and community development. British Educational Research Journal, 29(3), 417-433. doi:10. 1080/0141192031000156024.
Korten, D. C. (1986). Community management: Asian experiences and perspectives. West Hartford C.: Kumarian Press.

Masterson, J. H., Peacock, W. G., Van Zandt, S. S., Grover, H., Schwarz, L. F., \& Cooper, J. T. (2014). Planning for community resilience: A handbook for reducing vulnerability to disasters. Washington, DC: Island Press/Center for Resource Economics.

Miles, M. B., Huberman, A. M., \& Saldana, J. (2014). Qualitative data analysis: A methods sourcebook. California, CA: SAGE Publications.

Nahapiet, J., \& Ghoshal, S. (1998). Social capital, intellectual capital, and the organizational advantage. Academy of Management. The Academy of Management Review, 23(2), 242-266. doi:10.2307/259373.

Nakagawa, Y., \& Shaw, R. (2004). Social capital: A missing link to disaster recovery. International Journal of Mass Emergencies and Disasters, 22(1), 5-34.

Neace, M. B. (1999). Entrepreneurs in emerging economies: Creating trust, social capital, and civil society. Annals of the American Academy of Political and Social Science, 565(1), 148-161. doi:10.1177\% 2F000271629956500110.

Paton, D., \& Johnston, D. (2001). Disaster and communities: Vulnerability, resilence, and preparedness. Disaster Prevention and Management, 10(4), 270-277. doi:10.1108/EUM0000000005930.

Pemerintah Desa Girikerto. (2017). Monografi Desa Girikerto 2017. [Monograph of Girikerto Village 2017]. Yogyakarta: Desa Girikerto.

Putnam, R. D. (2000). Bowling alone: The collapse and revival of American community. New York, NY: Simon and Schuster. 
Rahayu, R., Ariyanto, D., Komariah, K., Hartati, S., Syamsiyah, J., \& Dewi, W. S. (2014). Dampak erupsi gunung merapi terhadap lahan dan upaya-upaya pemulihannya. Caraka Tani - Journal of sustainable agriculture, 29(1), 61-71. doi:10.20961/ carakatani.v29i1.13320.

Sanyal, S., \& Routray, J. K. (2016). Social capital for disaster risk reduction and management with empirical evidences from Sundarbans of India. International Journal of Disaster Risk Reduction, 19, 101-111. doi:10.1016/j.ijdrr.2016.08.010.

Selby, D., \& Kagawa, F. (2012). Disaster risk reduction in school curricula: Case studies from thirty countries. Geneva: UNESCO and UNICEF.

Suhardjo, D. (2011). Arti penting pendidikan mitigasi bencana dalam mengurangi resiko bencana. Cakrawala Pendidikan, O(2), 175-188. doi:10.21831/cp.v0i2.4226.

Sujarwo, S., Mulyadi, M., \& Tohani, E. (2015). Model pendidikan sadar lingkungan masyarakat korban erupsi merapi berbasis potensi lokal. Cakrawala Pendidikan, 34(01),12-23.doi:10.21831/cp.v1i1.4172.

Sumarno, S., \& Suryono, Y. (2014). Community based education approach in disaster preparedness and mitigation. Strengthening community resiliency to disaster through disaster education development. Yogyakarta: Universitas Negeri Yogyakarta.

Takeuchi, Y., Mulyasari, F., \& Shaw, R. (2011). Roles of family and community in disaster. In R. Shaw, K. Shiwaku, \& Y. Takeuchi (Eds.), Disaster education: Community, environment, and disaster management (Vol. 7, pp. 77-94). Bingley: Emerald Group Publishing Limited.
Tribunjogja.com. (2018, Juni). Tak melulu bersifat negatif, letusan gunung berapi juga memberikan dampak positif ini. [Not always negative, volcano eruption can have positive impact] From http://jogja. tribunnews.com/2018/06/01/tak-melulubersifat-negatif-letusan-gunung-berapijuga-memberikan-dampak-positif-ini.

UNESCO. (2008). Building community resilience to natural disasters through partnership: sharing experience and expertise in the region. New York, NY: United Nations Publication.

Westlund, H. (2006). Social capital in the knowledge economy: Theory and empirics. Berlin: Springer-Verlag.

Widodo, E., Widowati, A., \& Suyoso, S. (2014). Model revitalisasi sekolah terdampak erupsi merapi melalui pembuatan perangkat pembelajaran inovatif berbahan dasar limbah anorganik. Cakrawala Pendidikan,33(2), 277-285. doi:10.21831/ cp.v2i2.2167.

Wood, L. J., Boruff, B. J., \& Smith, H. M. (2013). When disaster strikes... How community cope and adapt: A social capital perspective. In C. D. Johnson(Ed.), Social capital: Theory, measurement and outcomes (pp. 143-169). New York, NY: Nova Science Publishers, Inc.

Woolcock, M. J. V. (1998). Social capital and economic development: Toward a theoretical synthesis and policy framework. Theory and Society, 27(2), 151-208. doi:10.1023/A:1006884930135.

Yin, R. K. (2015). Case study research: Designs and methods. California, CA: Sage Publication. 